\title{
Galectin 13 (PP13) Facilitates Remodeling and Structural Stabilization of Maternal Vessels during Pregnancy
}

\author{
Marei Sammar ${ }^{1, *}$, Tijana Drobnjak ${ }^{2}$, Maurizio Mandala ${ }^{3}$, Sveinbjörn Gizurarson ${ }^{2}$ (D), \\ Berthold Huppertz ${ }^{4,+}+$ ic and Hamutal Meiri ${ }^{5,+}$ \\ 1 Ephraim Katzir Department of Biotechnology Engineering, ORT Braude College, 2161002 Karmiel, Israel \\ 2 Faculty of Pharmaceutical Sciences, School of Health Science, University of Iceland, 107 Reykjavik, Iceland \\ 3 Department of Biology, Ecology and Earth Sciences, University of Calabria, 87030 Rende, Italy \\ 4 Department of Cell Biology, Histology and Embryology, Gottfried Schatz Research Center, \\ Medical University of Graz, 8010 Graz, Austria \\ 5 Hylabs Ltd., Rehovot, 7670606 and TeleMarpe Ltd., 6908742 Tel Aviv, Israel \\ * Correspondence: sammar@braude.ac.il; Tel.: +972-(4)-9901769 \\ + These authors contributed equally to this work.
}

Received: 10 June 2019; Accepted: 25 June 2019; Published: 29 June 2019

\begin{abstract}
Galectins regulate cell growth, proliferation, differentiation, apoptosis, signal transduction, mRNA splicing, and interactions with the extracellular matrix. Here we focus on the galectins in the reproductive system, particularly on a group of six galectins that first appears in anthropoid primates in conjunction with the evolution of highly invasive placentation and long gestation. Of these six, placental protein 13 (PP13, galectin 13) interacts with glycoproteins and glycolipids to enable successful pregnancy. PP13 is related to the development of a major obstetric syndrome, preeclampsia, a life-threatening complication of pregnancy which affects ten million pregnant women globally. Preeclampsia is characterized by hypertension, proteinuria, and organ failure, and is often accompanied by fetal loss and major newborn disabilities. PP13 facilitates the expansion of uterine arteries and veins during pregnancy in an endothelial cell-dependent manner, via the eNOS and prostaglandin signaling pathways. PP13 acts through its carbohydrate recognition domain that binds to sugar residues of extracellular and connective tissue molecules, thus inducing structural stabilization of vessel expansion. Further, decidual PP13 aggregates may serve as a decoy that induces white blood cell apoptosis, contributing to the mother's immune tolerance to pregnancy. Lower first trimester PP13 level is one of the biomarkers to predict the subsequent risk to develop preeclampsia, while its molecular mutations/polymorphisms that are associated with reduced PP13 expression are accompanied by higher rates of preeclampsia We propose a targeted PP13 replenishing therapy to fight preeclampsia in carriers of these mutations.
\end{abstract}

Keywords: Placental protein 13; Gal 10; Gal 13; Gal 14; Gal 16; preeclampsia; FGR; polymorphism; risk prediction; biomarkers; eNOS

\section{Galectins}

Galectins are a class of carbohydrate binding proteins with high affinity to $\beta$-galactoside sugars that bind to them via their $\mathrm{N}$ - or- O-linked glycosylation [1,2]. They share primary structural homology in their carbohydrate-recognition domains (CRDs) included in a canonical sequence of $~ 130$ amino acid backbone. They are synthesized as cytosolic proteins and reside in the cytosol or nucleus for much of their lifetime [3]. They form a $\beta$-sandwich $[4,5]$ consisting of five or six anti-parallel $\beta$-sheet strands [6], forming a shallow groove for holding a disaccharide or oligosaccharide. Eight amino acids 
form the CRD motif within this groove to mediate non-covalent binding. Additional amino acids enhance the specific interaction [5-9]. High affinity to the ABO blood groups is responsible for their hemagglutinin activity $[10,11]$. The galectins are classified into three categories [2]: (1) the prototype homo-dimers (gals 1, 2, 5, 7, 13-17, 19, 20), (2) the "tandem-repeat dimers" (gals 4, 6, 8, 9, 12) with short linkers, and (3) chimera-lectin (gal 3), with a C-terminal CRD and an N-terminal non-lectin for multimerization [12-15]. The multi-valent interaction facilitates crosslinking of signaling pathways, the formation of cell surface lattices, and endocytosis at the cell surface or in intracellular locations [16,17].

Today, we know of 20 members of the galectin family that interact with a plethora of molecules involved in inflammation, immune responses, cell trafficking, apoptosis, autophagy, trans-membrane signaling, and interactions with cytosolic and nuclear targets, nuclear transcription, gene expression, or mRNA splicing [18-21]. Galectins are able to translocate from intra- to extracellular compartments, and back. They affect signal transduction and apoptosis, growth, fibrosis, aggregation, adhesion, and cancer metastasis [22-27]. Hence, galectins are incorporated in the development of new therapeutics [22,27-29], and some are already in clinical development stages (https://galecto.com/ [30]).

\section{The Placental Galectins}

A variety of galectins are expressed in the reproductive system. They are pleiotropic regulators of key functions in the reproductive tract. Gal-1 and Gal-3 are involved in regulating signaling pathways at the feto-maternal interface $[31,32]$ and are expressed in the endometrium and the decidua. The tandem repeat of Gal-8 acts through spliced variants in various reproductive tissues [1-21]. Gal-9 is abundant via its three encoding genes [33]. In this respect, it is worth mentioning that the Gal 10 protein is also expressed by white blood cells (WBC), while its mRNA is exclusively expressed in bone marrow tissues. However, the WBC reach the reproductive system and influence this system during the process of pregnancy development, especially via generating an immune response against foreign (paternal) genes of the fetus and placenta [34,35]. Other galectins in the reproductive tract such as Gal-13 participate in trophoblast invasion into the decidua, spiral artery remodeling, and immune tolerance of maternal tissues to pregnancy [2].

Here we focus on a placental cluster of six galectins in anthropoid primates in the context of evolution of the highly invasive placentation and long gestation [31]. The expression of these galectins in the placental syncytiotrophoblast is altered in preeclampsia and early fetal growth restriction (FGR) [32]. Three of them, Gal-13, Gal-14, and Gal-16 are uniquely expressed in the placenta, indicating the massive differentiation effort dedicated by nature for assuring the establishment and maintenance of pregnancy in eutherian mammals [36].

\section{Galectin 13}

\subsection{The PP13 Protein and its $m R N A$}

Galectin 13 (Gal-13), also known as LGALS13 and placental protein 13 (PP13), is the most studied galectin of the anthropoid primates. As one of a six cluster primate genes, it is located on chromosome $19 \mathrm{q} 13$ [32], and is one of 56 known placental proteins. It was first isolated from human term placenta in 1983 and characterized by Bohn et al. [37]. Normal term placenta has approximately $2.5 \mathrm{mg}$ of PP13, and, according to Bohn, PP13 represents $~ 7 \%$ of the total placental proteins. PP13 shows structural and functional homologies to the ß-galactoside-binding lectins [1], with high homology to the other members of the cluster in their CRD $[31,32,38,39]$. Although so far no specific individual receptor for PP13 (in the classical sense) has been identified, affinity chromatography and mass spectroscopy determined high affinity binding of PP13 to annexin Ila, a member of $\mathrm{Ca} 2+$ and phospholipid binding proteins of the extracellular matrix, and to beta/gamma actin in the cytoplasm [10,40]. PP13 has high affinity to sugar residues, especially to $\mathrm{N}$-acetyl glucose amine, fucose, and $\mathrm{N}$-acetyl galactose amine [10]. It also binds sugar residues of the $B$ and $A B$ antigen of the $A B O$ blood groups [11], a binding that regulates the availability of free PP13 in the blood of pregnant women. This binding has 
been found to influence the risk assessment and preeclampsia prediction of PP13 [41], as will be further detailed below.

PP13 is expressed from a very early stage of pregnancy, and can be detected in the maternal blood already at week five of gestation [42], or 3 weeks after embryo return in IVF (Meiri, unpublished results). Immunohistochemistry and RNA hybridization studies have pointed to its predominant localization in the placental syncytiotrophoblast layer, placental blood vessels, and specific sites within the placental bed $[31,42,43]$. Early studies by Than et al. indicated its presence in the syncytiotrophoblast [10]. PP13 is detected in the cytoplasm and mainly along the apical plasma membrane of the syncytiotrophoblast [42,43]. It can also be detected in their nuclei, at least during very early gestation [43]. In cases of oxidative stress, strong staining for PP13 appears in the increasingly appearing syncytiotrophoblast microparticles (STBM, or necrotic bodies) $[42,44]$. A process of aponecrosis is accompanied by placental shedding of STBM during preeclampsia [42,45].

\subsection{Insights on the Gene and Protein Structures}

The LGALS13 gene encodes for PP13, and is comprised of a long promoter region at the 5 prime end followed by four exons: E1 (60 bp), E2 (72 bp), E3 (211 bp), and E4 (251 bp) spaced by introns (Figure 1). Intronic regions vary between $499 \mathrm{bp}$ and $1834 \mathrm{bp}$ in length. Exon 4 and part of exon 3 of the LGALS13 gene exclusively code for the entire amino acids included in the CRD domain $[6,10,38,46]$.

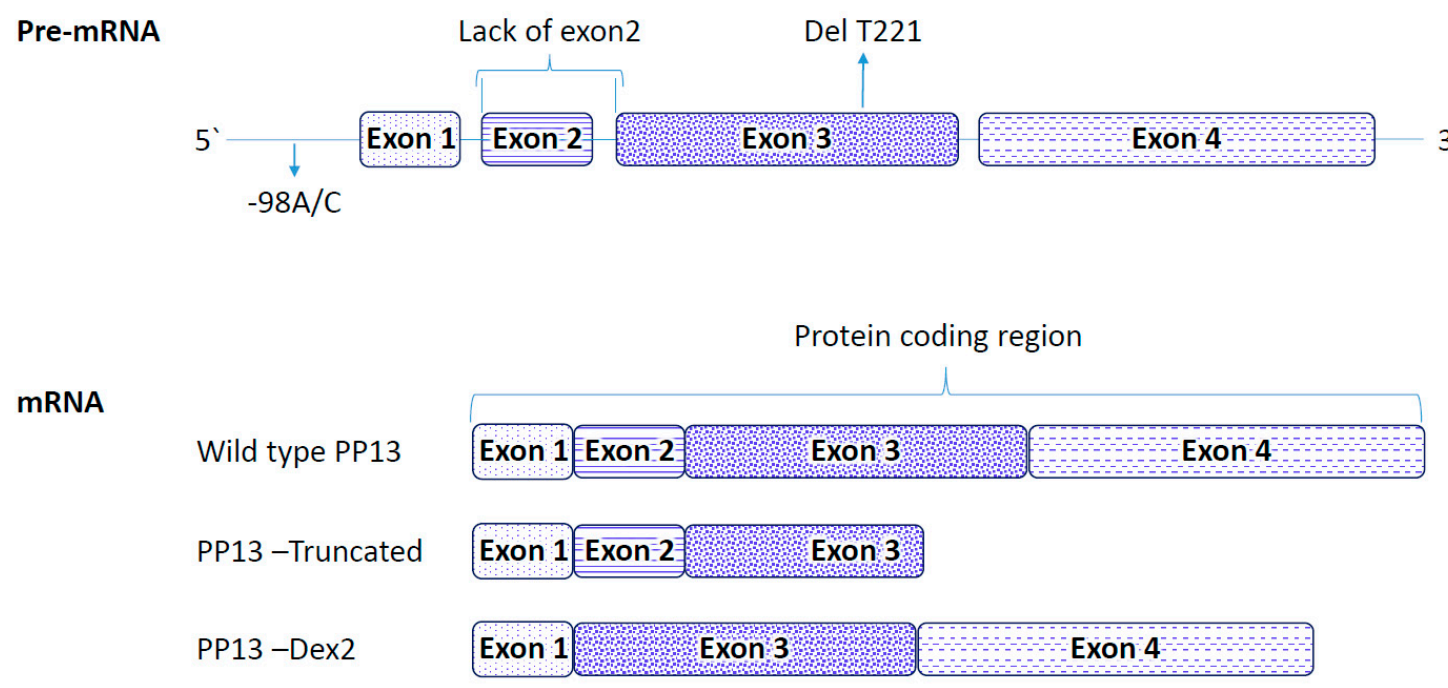

Figure 1. Schematic diagram of the LGALS13 gene and its mRNA variants. Top-The exons and introns are marked by boxes and lines, respectively. Lower panels represent the mRNA and the protein coding region. The wild type Gal-13 (PP13) consists of four full exons. The truncated Gal-13 variant $\operatorname{delT}_{221}$ is missing part of exon 3 and the full exon 4 , while the Dex-2 variant is missing exon 2 . The two variants - the truncated delT 221 variant and the spliced variant Dex-2 are both naturally occurring variants along with the promoter polymorphic variant of $-98 \mathrm{~A} / \mathrm{C}$.

The open reading frame of PP13 encodes for 139 amino acids [10,46]. The calculated molecular weight of the monomer is $\sim 16.12 \mathrm{kDa}$. In-vitro studies have shown that its expression is up-regulated by the binding of the TFAP2A transcription factor [32]. Other studies pointed to the link between PP13 expression and human chorionic gonadotropin (hCG) [47] that drives the fusion of villous cytotrophoblasts with the overlying syncytiotrophoblast [48]. Indeed, fusion of differentiating trophoblasts to form the syncytiotrophoblast is accompanied by increased PP13 expression. Fusion also increases PP13 expression in the trophoblast-derived BeWo cell line [47,49].

We engineered several recombinant PP13 variants. Initially, a Histidine-tag (His-PP13) variant was constructed, produced in E. coli, purified, and characterized [10,38]. The resultant His-PP13 fails to dimerize via disulfide bonds since the His-tag prohibits one of its cysteine $\mathrm{SH}$ residues from 
forming a dimer. The molecular conformation of such a monomeric state of PP13 prohibits the formation of the naturally occurring homodimer, and this variant tends to form a long chain of head-to-tail linked oligomers, which are characterized by low stability in solutions. Treatment of the His-PP13 variant with the reducing agent dithiothreitol (DTT) keeps the protein in a monomeric form, prohibiting the formation of long chain oligomers. This monomeric form exhibits long stability in solution, and in the presence of DTT lyophilized His-tag PP13 has an estimated shelf-life of 12 years or longer [50]. The second recombinant PP13 variant lacks the histidine tag (rPP13) and is expressed in E. coli $[38,51]$. The resultant protein was isolated from the inclusion bodies as a monomer that spontaneously homo-dimerizes to form a $32 \mathrm{kDa}$ protein that is very stable in aqueous solutions. Further aggregation to trimers and tetramers is marginal [46]).

\subsection{PP13 Secretion from the Placenta}

Lacking a signal sequence for transmembrane transport [6], it was estimated that the release of PP13 is accomplished in a manner typical to other galectins, namely via the liberation of extracellular vesicles $[12,52,53]$ (Figure 2). A release of un-packed protein via co-transfer with carrier proteins or endosomes was also suggested to be a calcium dependent mechanism [54,55]. In fact, it has been shown that the PP13 release from immortalized placental cells (BeWo cells) is significantly augmented with the use of a calcium ionophore [44]. Like other galectins, PP13 can re-enter cells by endocytosis via recycling of endocytic vesicles [56].

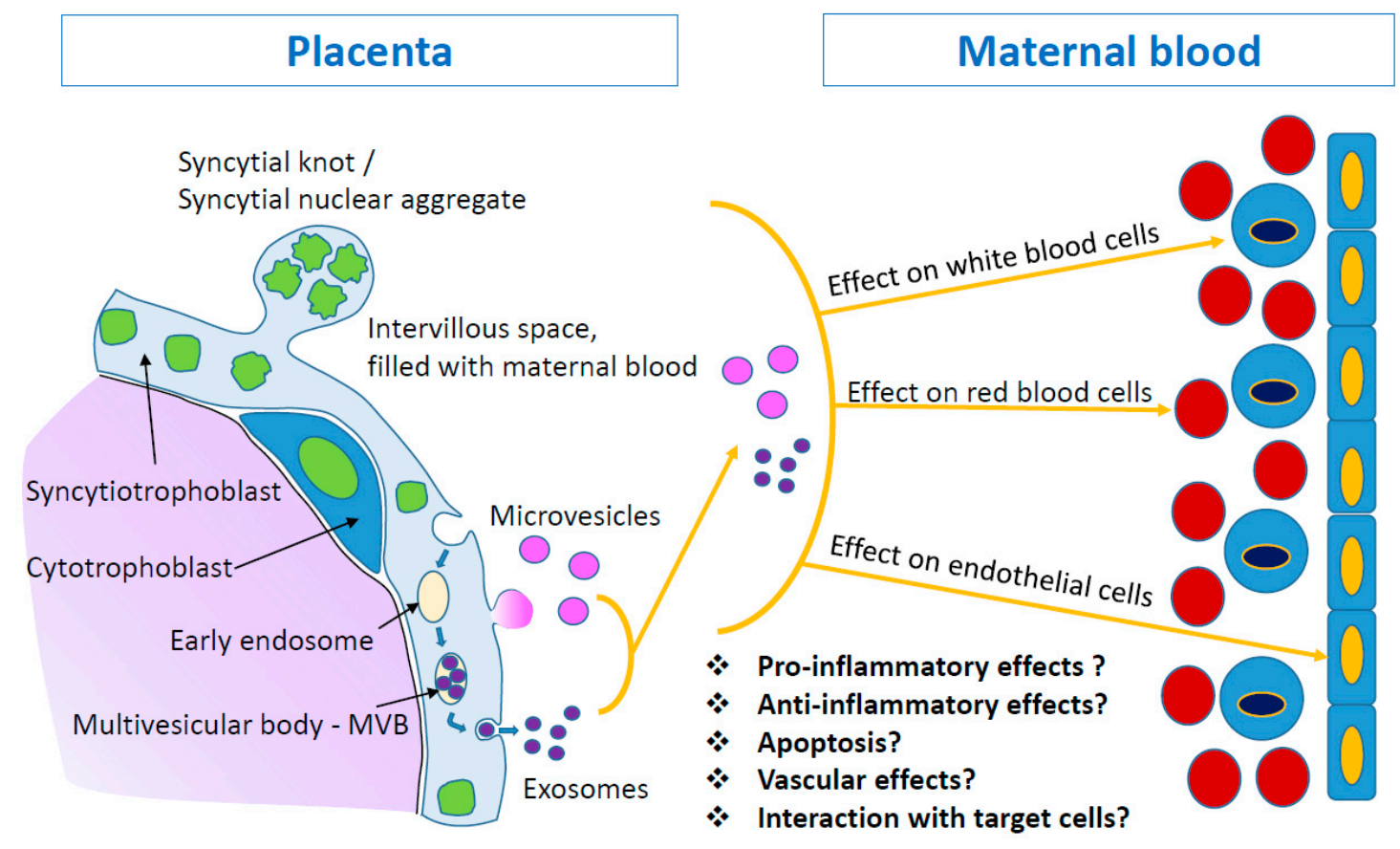

Figure 2. PP13 release from placental syncytiotrophoblast. Extracellular vesicles are cell-derived membrane particles, including exosomes (30-200 nm), microvesicles (100-1000 nm), and apoptotic bodies $(>1000 \mathrm{~nm})$. They are released from the placental syncytiotrophoblast layer. During normal turnover, the syncytiotrophoblast releases late-apoptotic syncytial knots (1-5 $\mu \mathrm{m})$ as large corpuscular structure into the maternal blood. At the same time, microvesicles and exosomes are released and can pass through capillary blood vessels. PP13 cargo of microvesicles and exosomes appears on both types of these extracellular vesicles, on the surface and inside the vesicles. These vesicles may interact with various cell types (red and white blood cells or endothelial cells) and convey different messages to the maternal body.

Sammar et al. [52] discovered a novel pathway for PP13 secretion that may be most relevant to the protein level in maternal blood. PP13 liberation is executed through the release of extracellular 
vesicles (EVs), mainly microvesicles and exosomes, carrying PP13 on the surface of EVs and/or inside them [52]. The microvesicles and exosomes that carry the PP13 cargo communicate with maternal organs to influence their response, both during normal and complicated pregnancies. Evidence has been obtained for the potential interaction of PP13 in such extracellular vesicles with red and white blood cells, as well as the endothelium (Figure 2).

\subsection{PP13 and Preeclampsia}

Preeclampsia, a severe life-threatening complication of pregnancy characterized by hypertension, proteinuria and organ failure [57-60] is mainly attributed to impaired placentation [61,62]. It affects ten million pregnant women globally, and is often accompanied by fetal loss and major newborn disabilities ([63]—www.preeclampsia.org). The hunting for serum markers to predict the risk to develop this pregnancy complication was a major challenge in the first decade of the 21st century [64]. We explored the potential use of PP13 as a biomarker for predicting the risk to develop preeclampsia. The availability of the purified native and recombinant PP13 have stimulated the generation of various poly- and monoclonal antibodies, followed by the development of an ELISA immune-diagnostic kit [50]. With these tools in hands, a comparative analysis of PP13 levels in maternal blood was conducted in multiple studies [65-68].

The studies have shown reduced concentrations of maternal blood PP13 in the first trimester in pregnancies that subsequently developed early, preterm and term preeclampsia with and without fetal growth restriction (FGR) [66,69-78]. Longitudinal studies have shown that in preeclampsia there is a sharp increase of PP13 between the first to the third trimester with the slope of change predicting the severity of the subsequent complication [42,75]. Such PP13 increase also predicts severe hemorrhage after delivery [79]. Interestingly, in twin pregnancies that subsequently develop preeclampsia, the level is very high already in the first trimester, indicating accelerated processes of impaired placentation in multiple pregnancy, corresponding with their higher frequency of the disorder [68].

In studies where term placentas were obtained after delivery, the mRNA levels of PP13 were 3.5-fold lower in women who developed PE and the related HELLP syndrome [45,65]. Additional studies have shown that the reduced PP13 mRNA can be determined already in the first trimester in patients who subsequently developed preeclampsia [80-82]. Unlike the protein level that tends to increase near the time of disease, low PP13 mRNA was detected throughout pregnancy. It was subsequently discovered by in-vitro placental explant studies that in a normal pregnancy the release of PP13 from a single placental villus is decreased from the first to the third trimester. During the first trimester of normal pregnancy the level of PP13 in maternal blood increases from 200-300 pg/mL to $400-600 \mathrm{pg} / \mathrm{mL}$ [42] due to the increase in the total number of villi during pregnancy [83]. In contrast, villi of preeclamptic placentas showed an elevated PP13 release at the time of disease [83]. It is estimated that aponecrotic release of PP13 from the large number of damaged villi accounts for the sharp slope of the PP13 level in maternal blood during the etiology of preeclampsia [36].

In a meta-analysis of 18 studies that investigated maternal blood levels of PP13 during the first trimester, reduced PP13 levels were found in women who subsequently developed preeclampsia about 20 weeks later. If evaluated in the first trimester as a single biomarker PP13 provided $83 \%$ detection rate for $10 \%$ false positive rate for early preeclampsia ( $<34$ weeks), $66 \%$ for preterm preeclampsia ( $<37$ weeks), and $47 \%$ for all cases of preeclampsia [66]. PP13 combined with first trimester Doppler pulsatility index of the blood flow through the maternal uterine arteries and the use of additional markers provides higher detection rates of preeclampsia in the first trimester $[66,84]$.

\subsection{PP13 Polymorphism and Preeclampsia}

Polymorphic variants of PP13 have been identified $[38,66]$, and three of them are important indicators of a high risk to develop preeclampsia:

(1) The "truncated" variant is a deletion of thymidine in position 221 of the open reading frame of exon $3[85,86]$. It was discovered among black and colored pregnant women in a Cohort of Cape Town, 
South African cohort [85]. It is associated with the development of an earlier stop codon coupled to a shorter PP13 variant ("truncated" or "delT221") [38]. The shorter delT221 variant is lacking the entire exon 4 and part of exon 3 [38] (Figure 1). Hence, delT221 is missing 2 of the amino-acids involved in the carbohydrate recognition domain (CRD), and two additional amino acids supporting carbohydrate binding $[6,31]$. Having this mutation in a heterozygous form is an effective predictor of severe early preeclampsia with $89 \%$ positive predictive value. Treatment of human leukocytes derived of the maternal decidua with the wild type of recombinant PP13 but not with the truncated PP13 induced apoptosis [31,43]. From this data it was speculated that one role of PP13 in pregnancy is to render the mother immune-tolerant to pregnancy. The immune tolerance is reached by binding of PP13 via the CRD to glycoproteins and glycolipids. Indeed, pregnancies carrying the homozygous DelT221 mutation are rejected by the mother and are not viable [86].

(2) The promoter variant. The $-98(\mathrm{~A} / \mathrm{C})$ promoter genotype displays three genotypes: the " $\mathrm{A} / \mathrm{A}$ " genotype (homozygous to the adenosine nucleotide), the " $\mathrm{C} / \mathrm{C}$ " genotype (homozygous to cytosine), or the "A/C" genotype (heterozygous form). In a South African as well as a London cohort of pregnant women, the A/A genotype was found to be associated with decreased expression of PP13 compared to the level of PP13 expression with either A/C or C/C genotypes in the -98 position [51,87]. The reduced expression was contributed in part by the impaired ability of the transcription factor TFAP2A to induce PP13 expression with the A/A genotype [51]. Accordingly, carriers of the A/A variant had an adjusted odds ratio of 3.68 to develop preeclampsia, while the $C / C$ or the $A / C$ genotypes rendered protection from developing preeclampsia. Combining the A/A genotype as a risk factor together with black ethnicity, history of previous preeclampsia, obesity (BMI > 37), and being at advanced maternal age provided an adjusted odds ratio of 14.0 and 7.0, respectively, for developing term or all preeclampsia cases [51].

(3) The Dex-2 variant. Recently, we were able to molecularly engineer a third molecular variant of PP13 that was denoted Dex-2. This mutant completely lacks the second exon (Figure 1). This additional natural PP13 variant was initially isolated in Israel while cloning PP13 DNA from a genomic library. The mutant clones were isolated from a placenta obtained after delivery from a woman with preeclampsia combined with FGR [55]. Burger et al. [55] have shown that PP13 which was isolated from a placenta of preeclampsia with FGR was inferior in inducing the liberation of free fatty acids from trophoblast membranes, and in causing the elevated release of prostaglandins. Further analysis of this mutant is warranted.

In summary, there may well be a link between reduced levels of PP13 during the first trimester of human pregnancy and the elevated risk for a subsequent development of preeclampsia. Preeclampsia patients may be a target population to evaluate if nourishing with the wild-type, full length PP13 can be used as a therapeutic tool to fight preeclampsia.

\subsection{PP13 and Immune Tolerance}

The syncytiotrophoblast secretes/releases PP13 from the first trimester and the protein reaches the decidua either via diffusion or via the maternal circulation, coinciding with the time of early trophoblast invasion. Kliman et al. [43] have shown the formation of PP13 aggregates closer to areas with increased apoptosis of various maternal immune cells. Killing these cells could enable us to promote extravillous trophoblast invasion of the uterine wall. In this manner, PP13 might serve to establish a decoy inflammatory response, sequestering maternal immune cells away from the site of extravillous trophoblast invading other sites of the uterine wall [31,39,43]. Accordingly, it was proposed that PP13 contributes to the immune tolerance of the mother to the invading trophoblasts. Having low levels of PP13 and/or having a mutated variant may decrease the level of PP13 secretion, thereby contributing to impaired placentation. 


\subsection{PP13 Replenishing Studies in Animals}

The uteroplacental circulation undergoes massive changes during pregnancy, resulting in a vascular system that is directing $20 \%$ of the total cardiac output to the uterine vascular bed. This results in more than a ten-fold increase in blood flow over the level present in the non-pregnant state [88]. Since in normal pregnancy there is only a small drop in blood pressure, it is necessary to gain uterine hemodynamic changes by uterine blood vessel expansion and reduced uterine vascular resistance [89]. In pregnancy, extravillous trophoblasts invade all types of luminal structures in the placental bed [90,91]. One of their major targets are spiral arteries and their adjacent stroma. The endoarterial trophoblast subpopulation [92] replaces and reorganizes the vascular smooth muscle and endothelial layers, resulting in the formation of low-resistance vessels that can accommodate a highly increased blood volume flowing towards the placenta [93]. These altered vessels are almost independent of maternal vasoconstriction through a lack of smooth muscle cells [89,94].

Through the invasive processes of the extravillous trophoblast, the vessels towards the intervillous space of the placenta (spiral arteries) and those draining blood back into the maternal system (uteroplacental veins) are connected to the placenta, resulting in a placental blood flow to sufficiently supply the placenta and the growing fetus with nutrients and oxygen [89,91]. This hemochorial type of placentation is present in mammals such as humans, higher order primates, rabbits, guinea pigs, mice, and rats [95-97]. At term there are around 200 spiral arteries opening towards the intervillous space, while the blood flow in the uterine artery is increased in volume with reduced velocity [96]. Impaired trophoblast invasion into spiral arteries results in higher blood flow velocities into the intervillous space of the placenta and thus damage of the fragile villous trees. [98-101].

PP13 appears to have an important role in these hemodynamic changes by facilitating expansion of the uterine vascular system during pregnancy to accommodate the increase of blood flow through the uterus and thus the placenta during pregnancy. The following in vivo data have been obtained using PP13 administration in different animal models:

- Initially, a single PP13 dosage injected intravenously into gravid rats and rabbits resulted in a reversible $\sim 30 \%$ reduction in blood pressure [102].

- In a second set of experiments, peristaltic pumps were implanted into gravid rats for a slow release of PP13 for 4 to 7 days from day 15 [102], or from day 8 of pregnancy [103]. rPP13 (compared to saline control) reversibly reduced blood pressure until the pumps released all their content. At delivery, 5 to 7 days after the active release of PP13 was over, treated animals had larger placentas and pups. Both the wild type rPP13 and the truncated variant DelT221 were effective in reducing blood pressure, but the truncated variant failed to sustain uterine artery expansion until the time of delivery [103].

- Isolated uterine mesenteric arteries from both mid-pregnant and non-pregnant rats were placed in arteriographs to measure their diameters and pressure in response to drug perfusion [104]. Uterine arteries of both pregnant and non-pregnant rats were dilated in a dose dependent manner with increasing concentrations of PP13. Half-maximal vasodilation of isolated arteries (EC50) was achieved at a concentration of 1pM PP13 (blood level of pregnant women). The effect was mediated by the endothelial layer, since stripping the vessels off the endothelial layer prohibited blood vessel expansion by PP13. Pharmacological analysis of the signaling pathways revealed that the vasodilation was mediated through signaling of the endothelial nitric oxide synthase (eNOS) and prostaglandin type 2 pathways [104].

- An additional study was performed with non-pregnant rats. Again, surgically implanted pumps released a constant dose of PP13 (rPP13 or His-PP13 variants) or saline over seven days. Some animals were sacrificed immediately after the end of PP13 release (on day 7), while others were sacrificed 6 days later (day 13) to compare the short and long-term impacts of PP13 on vessel growth and size. Both uterine veins and arteries were significantly expanded by rPP13 with a more pronounced effect after 13 days compared to the corresponding vessels after seven days. The long-term effect of treatment by rPP13 was more pronounced in the veins compared to the corresponding arteries. His-PP13 also expanded the blood vessels but the effect remained similar between 7 and 13 days, most 
likely since His-tag PP13 has only a monomeric form. This molecular variant does not turn into the natural configuration of a homo-dimer. It is estimated that to exert the structurally stable vascular expansion that is developed with the non His-tag protein, a molecular variant that forms a homo-dimer is required [105].

In conclusion, PP13 appears to play a key role in the remodeling of uterine arteries and veins during pregnancy, facilitating the adjustment of blood flow to and from the placenta. This way, PP13 adapts the uterus to provide increased but slower blood flow towards the placenta and back into the maternal system, necessary for normal pregnancy. PP13 acts via the NO and prostaglandin signaling pathways to provide oxygen and nutrients to the growing fetus (Figure 3).

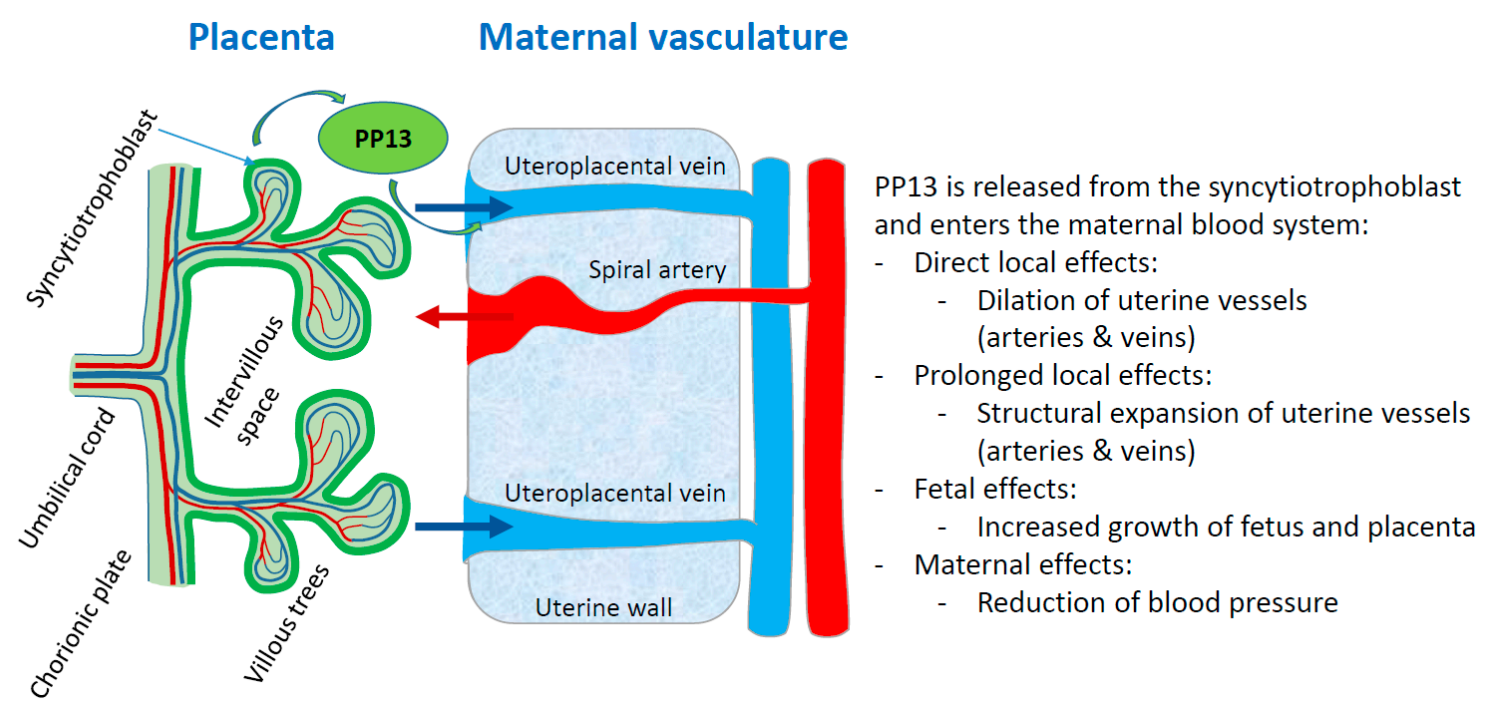

Figure 3. PP13 priming of maternal blood vessels. The scheme displays a comprehensive model of the PP13 effects on the vascular system of the mother. PP13 is released from the syncytiotrophoblast and enters the maternal blood system where it has different effects. The red arrow shows flow of maternal blood into the placenta via invaded spiral arteries, while the blue arrows indicate flow of maternal blood back from the placenta into the maternal vascular system via invaded uterine veins.

\subsection{Modeling the Role of PP13 in Pregnancy}

The PP13 molecule primes blood vessel expansion to adapt the uterine vascular system to supply oxygen and nutrients to the growing fetus. The effect supports the development of larger placentas and pups, as shown in a rat model [103]. The effect involves a chain of reactions, starting from a physiological effect that involves the endothelial layer through the e-NOS and prostaglandin signaling pathways [103], and continuing through structural stabilization of the surrounding components of the connective tissue around the blood vessels. Connective tissue stabilization requires the CRD component of the PP13 molecules that crosslinks between the endothelial layer and the connective tissue (Figure 4). Finally, PP13 acts as a decoy to attract maternal immune cells and thereby enabling the invasion of extravillous trophoblast into blood vessels [43].

Based on all the above we propose a targeted PP13 therapy to fight preeclampsia in patients with impaired PP13 and high risk to develop preeclampsia [106]. These patients could receive PP13 as a nourishing drug to support uterine vessel expansion and stabilization of blood supply during pregnancy. We are conducting preclinical studies and plan to evaluate the potential clinical impact testing animal models of preeclampsia to explore this hypothesis.

Considering the multifaceted nature of preeclampsia [58-60], the development of PP13 as a novel biological therapy to fight preeclampsia is now evaluated in certain animal models to provide a proof of concept. Among animal models, we plan to test (1) the reduced uterine placenta perfusion (RUPP model) in rats [107], (2) the transgenic mouse model of STOX-1 [108], and (3) the Baboon uteroplacental 
ischemia model [109], all identified as important model systems to evaluate novel drugs to fight preeclampsia [110,111].

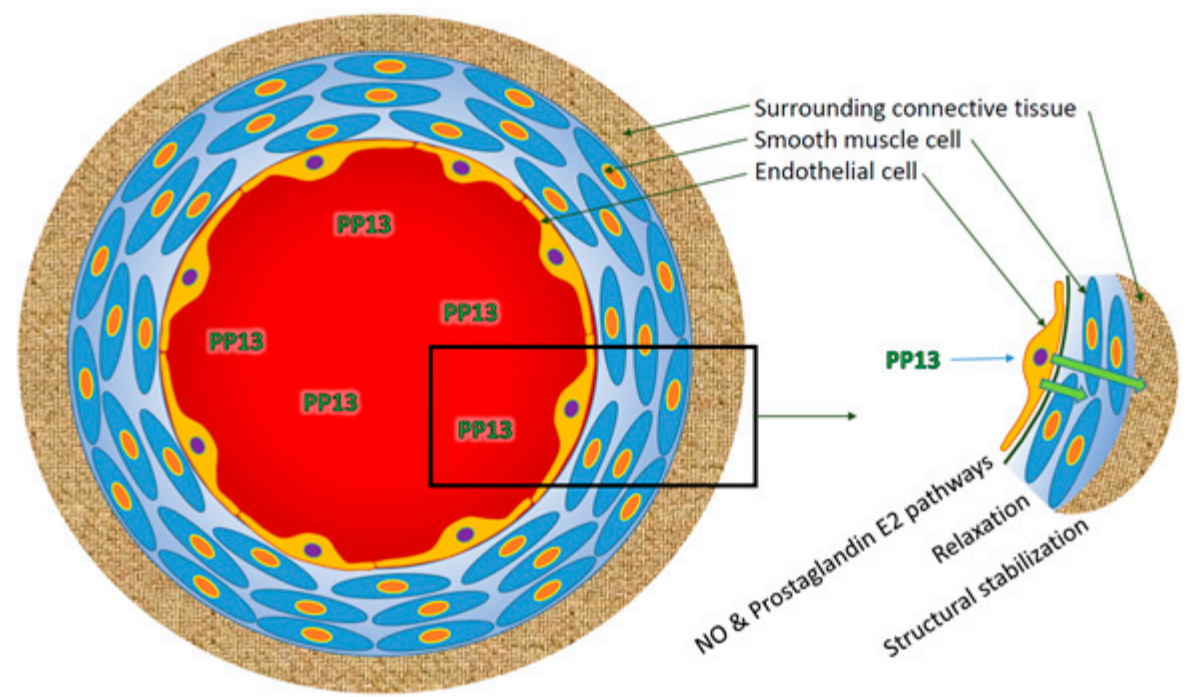

Figure 4. The effect of PP13 on the various layers of blood vessels. PP13 acts on the endothelial layer of the blood vessels and causes vasodilation by muscle relaxation through the signaling pathways of eNOS and prostaglandin 2. Further, PP13 causes stabilization of the surrounding connective tissues. Molecularly, this process requires the carbohydrate recognition domain to cross link between PP13 and molecules on the surface of the connective tissue and extracellular matrix.

\section{Multiple Galectins and Deep Placentation}

In this article we focus on PP13, a member of the cluster of 6 galectins that emerged during primate evolution, and are only found in anthropoids. These species differ from their strep-sirrhine counterparts by having hemochorial placentas associated with a reduction in the number of offspring, with just one infant being common in monkeys, humans and apes. In all of these species, the newborns have relatively large brains and long gestations [112,113]. As described before, the success of pregnancy is mediated via increased blood flow to and from the placenta, which is achieved via an invasive hemochorial placentation [114-116]. The genetic differences between the mother and the fetal semi-allograft necessitate the development of immune tolerance to reduce the danger of fetal rejection by the mother, considering the alloantigen aspect of eutherian pregnancies [32,114]. We have provided evidence for the crucial role of galectin 13 (PP13) to render the mother immune-tolerant to sustain the hemochorial placentation during the long gestation of anthropoid primates. Interestingly, it has been pointed out that in addition to PP13, the other members of the cluster of galectins of chromosome 19 in anthropoids share high homology in their sequence and placental localization ([117] https://www.ncbi.nlm.nih.gov/kis/ortholog/29124/?scope=9526\#genes-tab).

Table 1 indicates that humans have the entire cluster of which 5 are exclusively expressed in the placenta and one (Gal-10) is expressed in the bone marrow, but reaches the placenta via white blood cells, mainly eosinophils [2,31,32,39]. Orangutans, macaque, Sp. monkeys, and marmosets have four of the galectins, chimpanzees have two, and baboons, gorillas, and colobuses have only one galectin [31]. 
Table 1. Placental galectins in primates.

\begin{tabular}{|c|c|c|c|c|c|c|c|c|}
\hline Species & $\begin{array}{c}\text { Gal } 10 \\
\text { Eosinophils }\end{array}$ & $\begin{array}{c}\text { Gal } 13 \\
\text { Placenta }\end{array}$ & $\begin{array}{c}\text { Gal } 14 \\
\text { Placenta }\end{array}$ & $\begin{array}{c}\text { Gal } 16 \\
\text { Placenta }\end{array}$ & $\begin{array}{c}\text { Gal } 17 \\
\text { Placenta }\end{array}$ & $\begin{array}{c}\text { Gal } 20 \\
\text { Placenta }\end{array}$ & Count & $\begin{array}{c}\text { Invasion } \\
\text { Level }\end{array}$ \\
\hline Chimpanzee & & & & & & & 2 & $3+$ \\
\hline Orangutan & $10 \mathrm{~A}$ & & & & $17 \mathrm{C}$ & & 4 & $2+$ \\
\hline Baboon & & & & & & & 1 & $1+$ \\
\hline Human & $10 \mathrm{~A}$ & & & & $\begin{array}{l}17 \mathrm{~A} \\
17 \mathrm{~B}\end{array}$ & & $\begin{array}{c}5 \text { (with } 2 \text { subtypes } \\
\text { of Gal 17) }\end{array}$ & $4+$ \\
\hline Gorilla & & & & & & & 1 & $3+$ \\
\hline Colobus & & & & & & & 1 & $1+$ \\
\hline Macaque & & & & & $17 \mathrm{C}$ & & 4 & $2+$ \\
\hline Marmoset & $\begin{array}{l}10 \mathrm{~A} \\
10 \mathrm{~B} \\
10 \mathrm{C}\end{array}$ & & & & & & $\begin{array}{c}4 \text { (with } 3 \text { subtypes } \\
\text { of Gal 10) }\end{array}$ & $2+$ \\
\hline Sp. Monkeys & $\begin{array}{l}10 \mathrm{~A} \\
10 \mathrm{~B} \\
10 \mathrm{C}\end{array}$ & & & & & & $\begin{array}{c}4 \text { (with } 3 \text { subtypes } \\
\text { of Gal 10) }\end{array}$ & $2+$ \\
\hline Total species \# & 4 & 8 & 5 & 4 & 3 & 2 & & \\
\hline
\end{tabular}

The presence of placental galectins in primate placenta is provided following the analysis of the evolutionary differentiation tree $[31,32,36,39,115]$ with the exception of Galectin 10 (Gal 10) that is generated in bone-marrow but reaches the placenta via its expression in white blood cells. The letters A, B, and C reflect isoforms of the molecules. In terms of invasion: gorilla, chimpanzee, and human species have the deepest trophoblast invasion $(3+$ and $4+)$ reaching the inner myometrium [114-120]. The others have a much shallower implantation (1+ or 2+). The color code indicates in which species the Gal isoforms are expressed. The numbers in "total" refer to the numbers of species in which a specific Gal isoform is expressed. The numbers in "Count" refer to the numbers of Gal isoforms expressed in a given species.

Interestingly, all of the above species with the exception of the baboon, have PP13, most likely reflecting that this protein may be the first to be evolved or is derived from a common ancestor, and potentially it is the most essential one for a successful intrusive pregnancy [31]. The second most frequently found is Gal-14 that appears in four species. Gal-10 and Gal 16 are expressed in three species, while Gal-17 appears in two species and Gal-20 only in one. In terms of sequence homology, all galectins have close to $98 \%$ homology in the composition and configuration of their major amino acids of the carbohydrate recognition domain, the CRD. Gal-13 and Gal-16 share $73 \%$ amino acid sequence homology, while homology between Gal-13 and Gal-14 and between Gal-13 and Gal-10 is at the level of $68 \%$ and $57 \%$, respectively. Interestingly, human Gal-14 and baboon Gal-14 have $98 \%$ amino acid sequence homology [34,36].

According to Carter et al. [118] there are different models of placentation among apes. Yet, gorilla, chimpanzee, and human species have the deepest trophoblast invasion and their remodeling of the spiral arteries occurs deep into their inner myometrium [114-120]. All three have Gal-13 (PP13), while baboons with a much shallower trophoblast invasion only express Gal-14. Thus, having multiple co-expression of galectins appears to be essential for successful invasive pregnancy, in which PP13 is pivotal but may not be the only one required. The interplay between the different galectins and their composition is now under study to understand their crucial role in normal pregnancy and pregnancy complications.

Author Contributions: M.S., H.M. and B.H. conceptualized the work; M.S., T.D. and M.M. performed the experiments used as the basis for this work; H.M., M.S. and S.G. provided the resources for this work; M.S. and H.M. did the original draft preparation; all authors reviewed and edited the text; B.H. and M.S. drew the figures; M.S., H.M. and S.G. have lead funding acquisition.

Funding: This research was funded by Daniel Turnberg Fellowship, UK Academy of Medical Sciences and the EU COST action CA16113 - CkiniMark to M.S. This study was also sponsored in part by the European Union (FP7) through the ASPRE project (601852) to H.M., S.G. and T.D. were sponsored by Hananja ehf, and Icelandic Research Fund (Rannís), grant no. 163403-052.

Conflicts of Interest: The funders had no role in the design of the study; in the collection, analyses, or interpretation of data; in the writing of the manuscript, or in the decision to publish the results. Hamutal Meiri and Sveinbjorn Gizurarson have a patent for using PP13 for preeclampsia prevention. The other authors declare no conflict of interest. 


\section{Abbreviations}

$\begin{array}{ll}\text { ABO blood groups } & \text { Blood group types A, B, AB and O } \\ \text { BP } & \text { Base pair } \\ \text { CRD } & \text { Carbohydrate-recognition domain } \\ \text { EC }_{50} & \text { Effective dose for reaching 50\% effect } \\ \text { Enos } & \text { Endothelial nitric oxide synthase } \\ \text { Gal 1, Gal 3, etc. } & \text { Galectin 1, galectin 3 and other galectins according to their nomenclature } \\ \text { FGR } & \text { Fetal growth restriction } \\ \text { kDa } & \text { Kilo-Dalton } \\ \text { pMol } & \text { Pico molar quantity }\left(10^{-12} \mathrm{M}\right) \\ \text { PP13 } & \text { Placental protein } 13 \text { also called gal-13 and LGALS13 (gene) } \\ \text { STBM } & \text { Syncytiotrophoblast microparticles } \\ \text { WBC } & \text { White blood cells }\end{array}$

\section{References}

1. Barondes, S.H.; Castronovo, V.; Cooper, D.N.W.; Cummings, R.D.; Drickamer, K.; Felzi, T.; Gitt, M.A.; Hirabayashi, J.; Hughes, C.; Kasai, K.; et al. Galectins: A family of animal beta-galactoside-binding lectins. Cell 1994, 76, 597-598. [CrossRef]

2. Johannes, L.; Jacob, R.; Leffler, H. Galectins at a glance. J. Cell Sci. 2018, 131, jcs208884. [CrossRef] [PubMed]

3. Lindstedt, R.; Apodaca, G.; Barondes, S.H.; Mostov, K.E.; Leffler, H. Apical secretion of a cytosolic protein by Madin-Darby canine kidney cells. Evidence for polarized release of an endogenous lectin by a nonclassical secretory pathway. J. Biol. Chem. 1993, 268, 11750-11757. [PubMed]

4. Leffler, H.; Carlsson, S.; Hedlund, M.; Qian, Y.; Poirier, F. Introduction to galectins. Glycoconj. J. 2004, 19, 433-440. [CrossRef] [PubMed]

5. Visegrády, B.; Than, N.G.; Kilár, F.; Sümegi, B.; Than, G.N.; Bohn, H. Homology modelling and molecular dynamics studies of human placental tissue protein 13 (galectin-13). Protein Eng. 2001, 14, 875-880. [CrossRef] [PubMed]

6. Di Lella, S.; Sundblad, V.; Cerliani, J.P.; Guardia, C.M.; Estrin, D.A.; Vasta, G.R.; Rabinovich, G.A. When galectins recognize glycans: From biochemistry to physiology and back again. Biochemistry 2011, 50, 7842-7857. [CrossRef] [PubMed]

7. Hirabayashi, J.; Hashidate, T.; Arata, Y.; Nishi, N.; Nakamura, T.; Hirashima, M.; Urashima, T.; Oka, T.; Futai, M.; Muller, W.E.; et al. Oligosaccharide specificity of galectins: A search by frontal affinity chromatography. Biochim. Biophys. Acta 2002, 1572, 232-254. [CrossRef]

8. Kamili, N.A.; Arthur, C.M.; Gerner-Smidt, C.; Tafesse, E.; Blenda, A.; Dias-Baruffi, M.; Stowell, S.R. Key regulators of galectin-glycan interactions. Proteomics 2016, 16, 3111-3125. [CrossRef] [PubMed]

9. Salomonsson, E.; Carlsson, M.C.; Osla, V.; Hendus-Altenburger, R.; Kahl-Knutson, B.; Öberg, C.T.; Sundin, A.; Nilsson, R.; Nordberg-Karlsson, E.; Nilsson, U.J.; et al. Mutational tuning of galectin-3 specificity and biological function. J. Biol. Chem. 2010, 285, 35079-35091. [CrossRef] [PubMed]

10. Than, N.G.; Pick, E.; Bellyei, S.; Szigeti, A.; Burger, O.; Berente, Z.; Janaky, T.; Boronkai, A.; Kliman, H.; Meiri, H.; et al. Functional analyses of placental protein 13/galectin-13. Eur. J. Biochem. 2004, 71, 1065-1078. [CrossRef]

11. Than, N.G.; Romero, R.; Meiri, H.; Erez, O.; Xu, Y.; Tarquini, F.; Barna, L.; Szilagyi, A.; Ackerman, R.; Sammar, M.; et al. PP13, maternal ABO blood groups and the risk assessment of pregnancy complications. PLoS ONE 2011, 6, e21564. [CrossRef] [PubMed]

12. Seelenmeyer, C.; Wegehingel, S.; Tews, I.; Künzler, M.; Aebi, M.; Nickel, W. Cell surface counter receptors are essential components of the unconventional export machinery of galectin-1. J. Cell Biol. 2005, 171, 373-381. [CrossRef] [PubMed]

13. Hsu, D.K.; Zuberi, R.I.; Liu, F.T. Biochemical and biophysical characterization of human recombinant IgE-binding protein, an S-type animal lectin. J. Biol. Chem. 1992, 267, 14167-14174. [PubMed]

14. Massa, S.M.; Cooper, D.N.W.; Leffier, H.; Barondes, S.H. L-29, an endogenous lectin, binds to glycoconjugates ligands with positive cooperativity. Biochemistry 1993, 32, 260-267. [CrossRef] [PubMed] 
15. Kuklinski, S.; Probstmeier, R. Homophilic binding properties of galectin-3: Involvement of the carbohydrate recognition domain. J. Neurochem. 1998, 70, 814-823. [CrossRef] [PubMed]

16. Banani, S.F.; Lee, H.O.; Hyman, A.A.; Rosen, M.K. Biomolecular condensates: Organizers of cellular biochemistry. Nat. Rev. Mol. Cell Biol. 2017, 18, 285-298. [CrossRef] [PubMed]

17. Dennis, J.W. Many light touches convey the message. Trends Biochem. Sci. 2015, 40, 673-686. [CrossRef]

18. Dagher, S.F.; Wang, J.L.; Patterson, R.J. Identification of galectin-3 as a factor in pre-mRNA splicing. Proc. Natl. Acad. Sci. USA 1995, 92, 1213-1217. [CrossRef] [PubMed]

19. Vyakarnam, A.; Dagher, S.F.; Wang, J.L.; Patterson, R.J. Evidence for a role for galectin-1 in pre-mRNA splicing. Mol. Cell. Biol. 1997, 17, 4730-4737. [CrossRef] [PubMed]

20. Michaud, S.; Reed, R. An ATP-independent complex commits pre-mRNA to the mammalian spliceosome assembly pathway. Genes Dev. 1991, 5, 2534-2546. [CrossRef] [PubMed]

21. Kang, H.G.; Kim, D.H.; Kim, S.J.; Cho, Y.; Jung, J.; Jang, W.; Chun, K.H. Galectin-3 supports stemness in ovarian cancer stem cells by activation of the Notch1 intracellular domain. Oncotarget 2016, 7, 68229-68241. [CrossRef] [PubMed]

22. Blidner, A.G.; Méndez-Huergo, S.P.; Cagnoni, A.J.; Rabinovich, G.A. Re-wiring regulatory cell networks in immunity by galectin-glycan interactions. FEBS Lett. 2015, 589, 3407-3418. [CrossRef] [PubMed]

23. Thiemann, S.; Baum, L.G. Galectins and immune responses-just how do they do those things they do? Annu. Rev. Immunol. 2016, 34, 243-264. [CrossRef] [PubMed]

24. Glinsky, V.V.; Raz, A. Modified citrus pectin anti-metastatic properties: One bullet, multiple targets. Carbohydr. Res. 2009, 344, 1788-1791. [CrossRef] [PubMed]

25. Glinsky, V.V.; Glinsky, G.V.; Rittenhouse-Olson, K.; Huflejt, M.E.; Glinskii, O.V.; Deutscher, S.L.; Quinn, T.P. The role of Thomsen-Friedenreich antigen in adhesion of human breast and prostate cancer cells to the endothelium. Cancer Res. 2001, 61, 4851-4857.

26. Sindrewicz, P.; Lian, L.Y.; Yu, L.G. Interaction of the Oncofetal Thomsen-Friedenreich antigen with galectins in cancer progression and metastasis. Front. Oncol. 2016, 6, 79. [CrossRef]

27. Li, S.; Wandel, M.P.; Li, F.; Liu, Z.; He, C.; Wu, J.; Shi, Y.; Randow, F. Sterical hindrance promotes selectivity of the autophagy cargo receptor NDP52 for the danger receptor galectin-8 in antibacterial autophagy. Sci. Signal. 2013, 6, 9. [CrossRef]

28. Chen, W.S.; Cao, Z.; Leffler, H.; Nilsson, U.J.; Panjwani, N. Galectin-3 inhibition by a small-molecule inhibitor reduces both pathological corneal neovascularization and fibrosis. Investig. Ophthalmol. Vis. Sci. 2017, 58, 9-20. [CrossRef]

29. Delaine, T.; Collins, P.; MacKinnon, A.; Sharma, G.; Stegmayr, J.; Rajput, V.K.; Mandal, S.; Cumpstey, I.; Larumbe, A.; Salameh, B.A.; et al. Galectin-3-binding glycomimetics that strongly reduce bleomycin-induced lung fibrosis and modulate intracellular glycan recognition. ChemBioChem 2016, 17, 1759-1770. [CrossRef]

30. The Galectin Pharmacology List. Available online: https://galecto.com/ (accessed on 17 August 2018).

31. Than, N.G.; Romero, R.; Goodman, M.; Weckle, A.; Xing, J.; Dong, Z.; Xu, Y.; Tarquini, F.; Szilagyi, A.; Gal, P.; et al. A primate subfamily of galectins expressed at the maternal-fetal interface that promote immune cell death. Proc. Natl. Acad. Sci. USA 2009, 106, 9731-9736. [CrossRef]

32. Than, N.G.; Romero, R.; Xu, Y.; Erez, O.; Xu, Z.; Bhatti, G.; Leavitt, R.; Chung, T.H.; El-Azzamy, H.; LaJeunesse, C.; et al. Evolutionary origins of the placental expression of chromosome 19 cluster galectins, and their complex dysregulation in preeclampsia. Placenta 2014, 35, 855-865. [CrossRef]

33. Su, E.U.; Bi, S.; Kane, L.P. Galectin-9 regulates T helper cell function independently of Tim-3. Glycobiology 2011, 21, 1258-1265. [CrossRef]

34. Ackerman, S.J.; Liu, L.; Kwatia, M.A.; Savage, M.P.; Leonidas, D.D.; Swaminathan, G.J.; Acharya, K.R. Charcot-Leyden crystal protein (galectin-10) is not a dual function galectin with lysophospholipase activity but binds a lysophospholipase inhibitor in a novel structural fashion. J. Biol. Chem. 2002, 277, 14859-14868. [CrossRef] [PubMed]

35. Su, J. A brief history of Charcot-Leyden Crystal Protein/Galectin-10 research. Molecules 2018, $23,2931$. [CrossRef] [PubMed]

36. Than, N.G.; Romero, R.; Kim, C.J.; McGowen, M.R.; Papp, Z.; Wildman, D.E. Galectins: Guardians of eutherian pregnancy at the maternal-fetal interface. Trends Endocrinol. Metab. 2012, 23, 23-31. [CrossRef] [PubMed] 
37. Bohn, H.; Kraus, W.; Winckler, W. Purification and characterization of two new soluble placental tissue proteins (PP13 and PP17). Oncodev. Biol. Med. 1983, 4, 343-350. [PubMed]

38. Sammar, M.; Nisamblatt, S.; Gonen, R.; Huppertz, B.; Gizurarson, S.; Osol, G.; Meiri, H. The role of the carbohydrate recognition domain of placental protein 13 (PP13) in pregnancy evaluated with recombinant PP13 and the DelT221 PP13 variant. PLoS ONE 2014, 9, e102832. [CrossRef]

39. Than, N.G.; Romero, R.; Balogh, A.; Karpati, E.; Mastrolia, S.A.; Staretz-Chacham, O.; Hahn, S.; Erez, O.; Papp, Z.; Kim, C.J. Galectins: Double-edged swords in the cross-roads of pregnancy complications and female reproductive tract inflammation and neoplasia. J. Pathol. Transl. Med. 2015, 49, 181-208. [CrossRef]

40. Yang, R.Y.; Rabinovich, G.A.; Liu, F.T. Galectins: Structure, function and therapeutic potential. Expert Rev. Mol. Med. 2008, 10, e17. [CrossRef] [PubMed]

41. Burgess, A.; Johnson, T.S.; Simanek, A.; Bell, T.; Founds, S. Maternal ABO blood type and factors associated with preeclampsia subtype. Biol. Res. Nurs. 2019, 21, 264-271. [CrossRef] [PubMed]

42. Huppertz, B.; Sammar, M.; Chefetz, I.; Neumaier-Wagner, P.; Bartz, C.; Meiri, H. Longitudinal determination of serum placental protein 13 during development of preeclampsia. Fetal Diagn. Ther. 2008, 24, 230-236. [CrossRef] [PubMed]

43. Kliman, H.J.; Sammar, M.; Grimpel, Y.I.; Lynch, S.K.; Milano, K.M.; Pick, E.; Bejar, J.; Arad, A.; Lee, J.J.; Meiri, H.; et al. Placental protein 13 and decidual zones of necrosis: An immunologic diversion that may be linked to preeclampsia. Reprod. Sci. 2012, 19, 16-30. [CrossRef] [PubMed]

44. Balogh, A.; Pozsgay, J.; Matkó, J.; Dong, Z.; Kim, C.J.; Várkonyi, T.; Sammar, M.; Rigó, J., Jr.; Meiri, H.; Romero, R.; et al. Placental protein 13 (PP13/galectin-13) undergoes lipid raft-associated subcellular redistribution in the syncytiotrophoblast in preterm preeclampsia and HELLP syndrome. Am. J. Obstet. Gynecol. 2011, 205, 156.e1-156.e14. [CrossRef] [PubMed]

45. Than, N.G.; Abdul Rahman, O.; Magenheim, R.; Nagy, B.; Fule, T.; Hargitai, B.; Sammar, M.; Hupuczi, P.; Tarca, A.L.; Szabo, G.; et al. Placental protein 13 (galectin-13) has decreased placental expression but increased shedding and maternal serum concentrations in patients presenting with preterm pre-eclampsia and HELLP syndrome. Virchows Arch. 2008, 453, 387-400. [CrossRef] [PubMed]

46. Than, N.G.; Sumegi, B.; Than, G.N.; Berente, Z.; Bohn, H. Isolation and sequence analysis of a cDNA encoding human placental tissue protein 13 (PP13), a new lysophospholipase, homologue of human eosinophil Charcot-Leyden Crystal protein. Placenta 1999, 20, 703-710. [CrossRef] [PubMed]

47. Orendi, K.; Gauster, M.; Moser, G.; Meiri, H.; Huppertz, B. The choriocarcinoma cell line BeWo: Syncytial fusion and expression of syncytium-specific proteins. Reproduction 2010, 140, 759-766. [CrossRef] [PubMed]

48. Kliman, H.J.; Nestler, J.E.; Sermasi, E.; Sanger, J.M.; Strauss, J.F., III. Purification, characterization, and in vitro differentiation of cytotrophoblasts from human term placentae. Endocrinology 1986, 118, 1567-1582. [CrossRef] [PubMed]

49. Orendi, K.; Gauster, M.; Moser, G.; Meiri, H.; Huppertz, B. Effects of vitamins C and E, acetylsalicylic acid and heparin on fusion, beta-hCG and PP13 expression in BeWo cells. Placenta 2010, 31, 431-438. [CrossRef] [PubMed]

50. Meiri, H.; PP13. PP13. ELISA KIT for IVD of pregnancy complications. IDABC-EUDAMED: European Database on Medical Devices. Available online: http://ec.europa.eu/idabc/en/document/2256/5637.html. (accessed on 31 August 2008).

51. Madar-Shapiro, L.; Karady, I.; Trahtenherts, A.; Syngelaki, A.; Akolekar, R.; Poon, L.; Cohen, R.; Sharabi-Nov, A.; Huppertz, B.; Sammar, M.; et al. Predicting the risk to develop preeclampsia in the first trimester combining promoter variant-98A/C of LGALS13 (Placental Protein 13), black ethnicity, previous preeclampsia, obesity, and maternal age. Fetal Diagn. Ther. 2018, 43, 250-265. [CrossRef]

52. Sammar, M.; Dragovic, R.; Meiri, H.; Vatish, M.; Sharabi-Nov, A.; Sargent, I.; Redman, C.; Tannetta, D. Reduced placental protein 13 (PP13) in placental derived syncytiotrophoblast extracellular vesicles in preeclampsia-A novel tool to study the impaired cargo transmission of the placenta to the maternal organs. Placenta 2018, 66, 17-25. [CrossRef]

53. Hughes, R.C. Secretion of the galectin family of mammalian carbohydrate-binding proteins. Biochim. Biophys. Acta 1999, 1473, 172-185. [CrossRef]

54. Ideo, H.; Hoshi, I.; Yamashita, K.; Sakamoto, M. Phosphorylation and externalization of galectin-4 is controlled by Src family kinases. Glycobiology 2013, 23, 1452-1462. [CrossRef] [PubMed] 
55. Burger, O.; Pick, E.; Zwickel, J.; Kliman, M.; Meiri, H.; Slotky, R.; Mandel, S.; Rabinovitch, L.; Paltieli, Y.; Admon, A.; et al. Placental protein 13 (PP-13): Effects on cultured trophoblasts, and its detection in human body fluids in normal and pathological pregnancies. Placenta 2004, 25, 608-622. [CrossRef] [PubMed]

56. Furtak, V.; Hatcher, F.; Ochieng, J. Galectin-3 mediates the endocytosis of beta-1 integrins by breast carcinoma cells. Biochem. Biophys. Res. Commun. 2001, 289, 845-850. [CrossRef] [PubMed]

57. Walker, J.J. Pre-eclampsia. Lancet 2000, 356, 1260-1265. [CrossRef]

58. Roberts, J.M.; Cooper, H. Pathogenesis and genetics of pre-eclampsia. Lancet 2001, 357, 53-56. [CrossRef]

59. Redman, C.W.; Sargent, I. Latest advances in understanding preeclampsia. Science 2005, 308, $1592-1594$. [CrossRef] [PubMed]

60. World Health Organization. Maternal Mortality: To Improve Maternal Health, Barriers that Limit Access to Quality Maternal Health Services Must be Identified and Addressed at All Levels of the Health System: Fact Sheet. World Health Organization, 2014. Available online: https:/apps.who.int/iris/handle/10665/112318 (accessed on 9 June 2019).

61. Meekins, J.W.; Pijnenborg, R.; Hanssens, M.; McFadyen, I.R.; van Asshe, A. A study of placental bed spiral arteries and trophoblast invasion in normal and severe pre-eclamptic pregnancies. Br. J. Obstet. Gynaecol. 1994, 101, 669-674. [CrossRef]

62. Huppertz, B. Placental origins of preeclampsia: Challenging the current hypothesis. Hypertension 2008, 51, 970-975. [CrossRef]

63. The Preeclampsia Foundation. Available online: https://www.preeclampsia.org/ (accessed on 9 June 2019).

64. Cetin, I.; Huppertz, B.; Burton, G.; Cuckle, H.; Gonen, R.; Lapaire, O.; Mandia, L.; Nicolaides, K.; Redman, C.; Soothill, P.; et al. Pregenesys pre-eclampsia markers consensus meeting: What do we require from markers, risk assessment and model systems to tailor preventive strategies? Placenta 2011, 32, S4-S16. [CrossRef]

65. Sammar, M.; Nisemblat, S.; Fleischfarb, Z.; Golan, A.; Sadan, O.; Meiri, H.; Huppertz, B.; Gonen, R. Placenta-bound and body fluid PP13 and its mRNA in normal pregnancy compared to preeclampsia, HELLP and preterm delivery. Placenta 2011, 32, S30-S36. [CrossRef] [PubMed]

66. Huppertz, B.; Meiri, H.; Gizurarson, S.; Osol, G.; Sammar, M. Placental protein 13 (PP13): A new biological target shifting individualized risk assessment to personalized drug design combating pre-eclampsia. Hum. Reprod. Update 2013, 19, 391-405. [CrossRef]

67. Meiri, H.; Sammar, M.; Herzog, A.; Grimpel, Y.I.; Fihaman, G.; Cohen, A.; Kivity, V.; Sharabi-Nov, A.; Gonen, R. Prediction of preeclampsia by placental protein 13 and background risk factors and its prevention by aspirin. J. Perinat. Med. 2014, 42, 591-601. [CrossRef] [PubMed]

68. Maymon, R.; Trahtenherts, A.; Svirsky, R.; Melcer, Y.; Madar-Shapiro, L.; Klog, E.; Meiri, H.; Cuckle, H. Developing a new algorithm for first and second trimester preeclampsia screening in twin pregnancies. Hypertens Pregnancy 2017, 36, 108-115. [CrossRef] [PubMed]

69. Nicolaides, K.H.; Bindra, R.; Turan, O.M.; Chefetz, I.; Sammar, M.; Meiri, H.; Tal, J.; Cuckle, H.S. A novel approach to first-trimester screening for early pre-eclampsia combining serum PP-13 and Doppler ultrasound. Ultrasound Obstet. Gynecol. 2006, 27, 13-17. [CrossRef] [PubMed]

70. Spencer, K.; Cowans, N.J.; Chefetz, I.; Tal, J.; Meiri, H. First-trimester maternal serum PP-13, PAPP-A and second-trimester uterine artery Doppler pulsatility index as markers of pre-eclampsia. Ultrasound Obstet. Gynecol. 2007, 29, 128-134. [CrossRef] [PubMed]

71. Spencer, K.; Cowans, N.J.; Chefetz, I.; Tal, J.; Kuhnreich, I.; Meiri, H. Second-trimester uterine artery Doppler pulsatility index and maternal serum PP13 as markers of pre-eclampsia. Prenat. Diagn. 2007, 27, 258-263. [CrossRef]

72. Chafetz, I.; Kuhnreich, I.; Sammar, M.; Tal, Y.; Gibor, Y.; Meiri, H.; Cuckle, H.; Wolf, M. First-trimester placental protein 13 screening for preeclampsia and intrauterine growth restriction. Am. J. Obstet. Gynecol. 2007, 197, e1-e7. [CrossRef] [PubMed]

73. Cowans, N.J.; Spencer, K.; Meiri, H. First-trimester maternal placental protein 13 levels in pregnancies resulting in adverse outcomes. Prenat. Diagn. 2008, 28, 121-125. [CrossRef]

74. Romero, R.; Kusanovic, J.P.; Than, N.G.; Erez, O.; Gotsch, F.; Espinoza, J.; Edwin, S.; Chefetz, I.; Gomez, R.; Nien, J.K.; et al. First-trimester maternal serum PP13 in the risk assessment for preeclampsia. Am. J. Obstet. Gynecol. 2008, 199, 122.e1-122.e11. [CrossRef] 
75. Gonen, R.; Shahar, R.; Grimpel, Y.I.; Chefetz, I.; Sammar, M.; Meiri, H.; Gibor, Y. Placental protein 13 as an early marker for pre-eclampsia: A prospective longitudinal study. Br. J. Obstet. Gynaecol. 2008, 115, 1465-1472. [CrossRef] [PubMed]

76. Khalil, A.; Cowans, N.J.; Spencer, K.; Goichman, S.; Meiri, H.; Harrington, K. First trimester maternal serum placental protein 13 for the prediction of pre-eclampsia in women with a priori high risk. Prenat. Diagn. 2009, 29, 781-789. [CrossRef] [PubMed]

77. Khalil, A.; Cowans, N.J.; Spencer, K.; Goichman, S.; Meiri, H.; Harrington, K. First-trimester markers for the prediction of pre-eclampsia in women with a-priori high risk. Ultrasound Obstet. Gynecol. 2010, 35, 671-679. [CrossRef] [PubMed]

78. Meiri, H.; Huppertz, B.; Cetin, I. Development of early non-invasive markers and means for the diagnosis and progression monitoring of preeclampsia and tailoring putative therapies (project pregenesys 037244). Placenta 2011, 32, S1-S3. [CrossRef] [PubMed]

79. Farina, A.; Bernabini, D.; Zucchini, C.; De Sanctis, P.; Quezada, M.S.; Mattioli, M.; Rizzo, N. Elevated maternal placental protein 13 serum levels at term of pregnancy in postpartum major hemorrhage (>1000 mLs). A prospective cohort study. Am. J. Reprod. Immunol. 2017, 78, e12702. [CrossRef] [PubMed]

80. Shekizawa, A.; Purwosunu, Y.; Yoshimura, S.; Nakamura, M.; Shimizu, H. PP13 mRNA expression in trophoblasts from preeclamptic placentas. Reprod. Sci. 2009, 16, 408-413. [CrossRef] [PubMed]

81. Shimizu, H.; Sekizawa, A.; Purwosunu, Y.; Nakamura, M.; Farina, A.; Rizzo, N.; Okai, T. PP13 mRNA expression in the cellular component of maternal blood as a marker for preeclampsia. Prenat. Diagn. 2009, 29, 1231-1236. [CrossRef] [PubMed]

82. Farina, A.; Zucchini, C.; Sekizawa, A.; Purwosunu, Y.; de Sanctis, P.; Santarsiero, G.; Rizzo, N.; Morano, D.; Okai, T. Performance of messenger RNAs circulating in maternal blood in the prediction of preeclampsia at 10-14 weeks. Am. J. Obstet. Gynecol. 2010, 203, 575.e1-7. [CrossRef]

83. Grimpel, Y.I.; Kivity, V.; Cohen, A.; Meiri, H.; Sammar, M.; Gonen, R.; Huppertz, B. Effects of calcium, magnesium, low-dose aspirin and low-molecular-weight heparin on the release of PP13 from placental explants. Placenta 2011, 32, S55-S64. [CrossRef]

84. Than, N.G.; Balogh, A.; Romero, R.; Kárpáti, E.; Erez, O.; Szilágyi, A.; Kovalszky, I.; Sammar, M.; Gizurarson, S.; Matkó, J.; et al. Placental Protein 13 (PP13)-A placental immunoregulatory galectin protecting pregnancy. Front. Immunol. 2014, 20, 348. [CrossRef]

85. Gebhardt, S.; Bruiners, N.; Hillerman, R. A novel exonic variant (221delT) in the LGALS13 gene encoding placental protein 13 (PP13) is associated with preterm labour in a low risk population. J. Reprod. Immunol. 2009, 82, 166-173. [CrossRef] [PubMed]

86. Than, N.G.; Romero, R.; Hillermann, R.; Cozzi, V.; Nie, G.; Huppertz, B. Prediction of preeclampsia-a workshop report. Placenta 2008, 29, S83-S85. [CrossRef] [PubMed]

87. Bruiners, N.; Bosman, M.; Postma, A.; Gebhardt, S.; Rebello, G.; Sammar, M.; Meiri, H.; Hillermann, R. Promoter variant-98A-C of the LGALS13 gene and pre-eclampsia. In Proceedings of the 8th World Congress of Prenatal Medicine and Fetal Development, Florence, Italy, 7 September 2007.

88. Palmer, S.K.; Zamudio, S.; Coffin, C.; Parker, S.; Stamm, E.; Moore, L.G. Quantitative estimation of human uterine artery blood flow and pelvic blood flow redistribution in pregnancy. Obstet. Gynecol. 1992, 80, 1000-1006. [PubMed]

89. Thornburg, K.L.; Jacobson, S.L.; Giraud, G.D.; Morton, M.J. Hemodynamic changes in pregnancy. Semin. Perinatol. 2000, 24, 11-14. [CrossRef]

90. Moser, G.; Windsperger, K.; Pollheimer, J.; de Sousa Lopes, S.C.; Huppertz, B. Human trophoblast invasion: New and unexpected routes and functions. Histochem. Cell Biol. 2018, 150, 361-370. [CrossRef]

91. Moser, G.; Drewlo, S.; Huppertz, B.; Armant, D.R. Trophoblast retrieval and isolation from the cervix: Origins of cervical trophoblasts and their potential value for risk assessment of ongoing pregnancies. Hum. Reprod. Update 2018, 24, 484-496. [CrossRef]

92. Moser, G.; Huppertz, B. Implantation and extravillous trophoblast invasion: From rare archival specimens to modern biobanking. Placenta 2017, 56, 19-26. [CrossRef]

93. Kaufmann, P.; Black, S.; Huppertz, B. Endovascular trophoblast invasion: Implications for the pathogenesis of intrauterine growth retardation and preeclampsia. Biol. Reprod. 2003, 69, 1-7. [CrossRef]

94. Gokina, N.I.; Mandala, M.; Osol, G. Induction of localized differences in rat uterine radial artery behavior and structure during gestation. Am. J. Obstet. Gynecol. 2003, 189, 1489-1493. [CrossRef] 
95. Pijnenborg, R.; Vercruysse, L.; Hanssens, M. The uterine spiral arteries in human pregnancy: Facts and controversies. Placenta 2006, 27, 939-958. [CrossRef]

96. Pijnenborg, R.; Vercruysse, L.; Brosens, I. Deep placentation. Best Pract. Res. Clin. Obstet. Gynaecol. 2011, 25, 273-285. [CrossRef] [PubMed]

97. Moll, W. Structure adaptation and blood flow control in the uterine arterial system after hemochorial placentation. Eur. J. Obstet. Gynecol. Reprod. Biol. 2003, 110, S19-S27. [CrossRef]

98. Burton, G.J.; Woods, A.W.; Jauniaux, E.; Kingdom, J.C. Rheological and physiological consequences of conversion of the maternal spiral arteries for uteroplacental blood flow during human pregnancy. Placenta 2009, 30, 473-482. [CrossRef] [PubMed]

99. Browne, V.A.; Julian, C.G.; Toledo-Jaldin, L.; Cioffi-Ragan, D.; Vargas, E.; Moore, L.G. Uterine artery blood flow, fetal hypoxia and fetal growth. Philos. Trans. R. Soc. B Biol. Sci. 2015, 370, 20140068. [CrossRef] [PubMed]

100. Konje, J.C.; Kaufmann, P.; Bell, S.C.; Taylor, D.J. A longitudinal study of quantitative uterine blood flow with the use of color power angiography in appropriate for gestational age pregnancies. Am. J. Obstet. Gynecol. 2001, 185, 608-613. [CrossRef] [PubMed]

101. Mandala, M.; Osol, G. Physiological remodelling of the maternal uterine circulation during pregnancy. Basic Clin. Pharmacol. Toxicol. 2012, 110, 12-18. [CrossRef] [PubMed]

102. Gizurarson, S.; Huppertz, B.; Osol, G.; Skarphedinsson, J.O.; Mandala, M.; Meiri, H. Effects of placental protein 13 on the cardiovascular system in gravid and non-gravid rodents. Fetal Diagn. Ther. 2013, 33, 257-264. [CrossRef] [PubMed]

103. Gizurarson, S.; Sigurdardottir, E.R.; Meiri, H.; Huppertz, B.; Sammar, M.; Sharabi-Nov, A.; Mandalá, M.; Osol, G. Placental protein 13 administration to pregnant rats lowers blood pressure and augments fetal growth and venous remodeling. Fetal Diagn. Ther. 2016, 39, 56-63. [CrossRef] [PubMed]

104. Drobnjak, T.; Gizurarson, S.; Gokina, N.I.; Meiri, H.; Mandalá, M.; Huppertz, B.; Osol, G. Placental protein 13 (PP13)-induced vasodilation of resistance arteries from pregnant and nonpregnant rats occurs via endothelial-signaling pathways. Hypertens. Pregnancy 2017, 36, 86-95. [CrossRef]

105. Drobnjak, T.; Jónsdóttir, A.M.; Helgadóttir, H.; Runólfsdóttir, M.S.; Meiri, H.; Sammar, M.; Osol, G.; Mandalà, M.; Huppertz, B.; Gizurarson, S. Placental protein 13 (PP13) stimulates rat uterine vessels after slow subcutaneous administration. Int. J. Womens Health 2019, 11, 213-222. [CrossRef]

106. Meiri, H.; Osol, G.; Cetin, I.; Gizurarson, S.; Huppertz, B. Personalized therapy against preeclampsia by replenishing placental protein 13 (PP13) targeted to patients with impaired PP13 molecule or function. Comput. Struct. Biotechnol. J. 2017, 15, 433-446. [CrossRef] [PubMed]

107. Li, J.; LaMarca, B.; Reckelhoff, J.F. A model of preeclampsia in rats: The reduced uterine perfusion pressure (RUPP) model. Am. J. Physiol. Heart Circ. Physiol. 2012, 303, H1-H8. [CrossRef] [PubMed]

108. Collinot, H.; Marchiol, C.; Lagoutte, I.; Lager, F.; Siauve, N.; Autret, G.; Balvay, D.; Renault, G.; Salomon, L.J.; Vaiman, D. Preeclampsia induced by STOX1 overexpression in mice induces intrauterine growth restriction, abnormal ultrasonography and BOLD MRI signatures. J. Hypertens. 2018, 36, 1399-1406. [CrossRef] [PubMed]

109. Makris, A.; Yeung, K.R.; Shirlene, M.; Lim, S.L.; Sunderland, N.; Heffernan, S.; Thompson, J.F.; Iliopoulos, J.; Killingsworth, M.C.; Yong, J.; et al. Placental growth factor reduces blood pressure in a uteroplacental ischemia model of preeclampsia in non-human primates. Hypertension 2016, 67, 1263-1272. [CrossRef] [PubMed]

110. Grimes, P.S.; Bombay, K.; Lanes, A.; Walker, M.; Daniel, J.; Corsi, D.J. Potential biological therapies for severe preeclampsia: A systematic review and meta-analysis. BMC Pregnancy Childbirth 2019, 19, 163. [CrossRef]

111. Gunnarsson, R.; Akerstorm, B.; Hansson, S.R.; Gram, M. Recombinant alpha-1-microglobulin: A potential treatment for preeclampsia. Drug Dis. Today 2017, 22, 736-743. [CrossRef] [PubMed]

112. Chavatte-Palmer, P.; Tarrade, A. Placentation in different mammalian species. Ann. Endocrinol. 2016, 77, 67-74. [CrossRef]

113. Enders, A.C.; Carter, A.M. The evolving placenta: Different developmental paths to a hemochorial relationship. Placenta 2012, 3, S92-S98. [CrossRef]

114. Wildman, D.E.; Chen, C.; Erez, O.; Grossman, L.I.; Goodman, M.; Romero, R. Evolution of the mammalian placenta revealed by phylogenetic analysis. Proc. Natl. Acad. Sci. USA 2006, 103, 3203-3208. [CrossRef] 
115. Wildman, D.E.; Uddin, M.; Romero, R.; Gonzalez, J.M.; Than, N.G.; Murphy, J.; Hou, Z.C.; Fritz, J. Spontaneous abortion and preterm labor and delivery in nonhuman primates: Evidence from a captive colony of chimpanzees (Pan troglodytes). PLoS ONE 2011, 6, e24509. [CrossRef]

116. Roberts, M.R.; Green, J.A.; Schulz, L.C. The evolution of the placenta. Reproduction 2016, 152, R179-R189. [CrossRef] [PubMed]

117. Searching for Orthologous Genes at NCBI. Available online: https://www.ncbi.nlm.nih.gov/kis/ortholog/ 29124/?scope=9526\#genes-tab (accessed on 9 June 2019).

118. Carter, A.M. Recent advances in understanding evolution of the placenta: Insights from transcriptomics. F1000Research 2018, 7. [CrossRef] [PubMed]

119. Hou, Z.C.; Sterner, K.N.; Romero, R.; Than, N.G.; Gonzalez, J.M.; Weckle, A.; Xing, J.; Benirschke, K.; Goodman, M.; Wildman, D.E. Elephant transcriptome provides insights into the evolution of eutherian placentation. Genome Biol. Evol. 2012, 4, 713-725. [CrossRef] [PubMed]

120. Pijnenborg, R.; Vercruysse, L.; Carter, A.M. Deep trophoblast invasion and spiral artery remodelling in the placental bed of the lowland gorilla. Placenta 2011, 32, 586-591. [CrossRef] [PubMed]

(C) 2019 by the authors. Licensee MDPI, Basel, Switzerland. This article is an open access article distributed under the terms and conditions of the Creative Commons Attribution (CC BY) license (http://creativecommons.org/licenses/by/4.0/). 